\title{
Peace Governance and Multiculturalism: What role for Peace Education in the Balkans
}

\author{
Lidija Georgieva \\ UNESCO Chair in Intercultural Studies and Research, Faculty of Philosophy, UKIM¹
}

\begin{abstract}
This article will focus on theoretical and practical dilemmas related to the concept of peace governance, and within this context on the possible transformative role of peace education trough facilitation of contact between communities in conflict. The basic assumption is that violent conflicts in the Balkans have been resolved trough negotiated settlements and peace agreements. Yet, education strategy including peace education and its impact on post-conflict peacebuilding and reconciliation are underestimated. Peace governance is recognized as a dynamic but challenging process often based on institutional and policy arrangements aimed to at least settle conflict dynamics or in some cases even to provide more sustainable peace after signing of negotiated settlement in multicultural societies. We will argue that education in general is one of the critical issues of peace governance arrangements that could facilitate peacebuilding and create a contact platform between communities. The first question addressed in this article is to what extend peace agreements refer to education as an issue and the second one relate to the question if education is included in peace agreement to what extent it contributes for contact between different conflicting communities. Although it is widely accepted that contacts between former adversaries contributes for multicultural dialogue it is less known or explained if and in what way peace agreements provisions on education facilitate contact and transformation of conflicting relations.
\end{abstract}

Keywords: Peace Governance and Multiculturalism: What role for Peace Education in the Balkans

\section{Introduction}

\section{The Aim}

The purpose of this paper is to contribute for ongoing theoretical discussion in mainstream IR studies and to liberal peacebuilding argumentation that traditional and neoliberal strategies are most successful cure for conflict prone or multicultural societies devastated by violent conflicts. In addition we will develop discussion about utility of liberal peacebuilding tools and conflict management strategies in parallel with discussion about peace governance as a concept that supports argumentation about necessity of long term and sustainable strategies and tools for sustainable peacebuilding.

Although much of this debates are based on issues concerned with the effectiveness of international interventions in containment of violent conflicts and questions that predominantly refer to political and security sector reforms in this paper we will question centrality (or more precisely), marginalization of peace education in peacebuilding and international intervention strategies. The set of main questions are why education is not referred or it is treated as subordinated issue in most of peace agreements in the postconflict Balkan settings? Another important question is if education is referred as an issue within peace agreements, how it contributes for conflict dynamics de-escalation or for communication among different, conflicting groups in the society? More specific interest of this paper is to open discussion about how peace agreements that included references and prescriptions about education are transformed into peace governance strategies and could contribute for effective communication between conflicting actors in multicultural societies in the Balkans.

\footnotetext{
${ }^{1}$ Correspondence address: Georgieva@fzf.ukim.edu.mk Lidija Georgieva is professor and Chair holder of UNESCO Chair in Intercultural Studies and Research at Faculty of Philosophy, University Ss Cyril and Methodius 


\section{Peace Governance and/or peacebuilding}

Richmond once emphasized that although it is generally assumed that liberal peace is acceptable to all and is unproblematic in its internal structure yet its acceptance in post conflict zones is far from smooth (Richmond, 2013).

Different questions related to the issue of education and its role in stabilization of both democratic and conflict prone counties were investigated and elaborated as a part of broad peacebuilding and conflict transformation theoretical debates or research endeavors. The general perspectives that marked almost two decades long debate about un/successfulness of this conceptions and numerous international interventions undertaken after 1991 were broadly related to western model of liberal peace, its three guiding principles (market economy, rule of law and democracy) and policies of the UN, the World Bank, the OECD-DAC and bilateral donors. In parallel the peacebuilding concept and its forms were upgraded and original content of the concept after its emergence as an UN approach to postconflict challenges up to nowadays gradually incorporated rang of activities before, during and after the initiation of peace agreement. The evolution of peacebuilding as a concept and method does not provided more clarity or consensus about questions if and how concept of liberal democracy will bring conflicting society into consolidation. If classical liberal peacebuilding assumption is that non-functioning state is one of core reasons for conflict and instability than it is understandable that state centric approach and building of governmental institutions are considered as preconditions for successful peacebuilding. Francis (2010) argues that we should differentiate between pacification and peacebuilding as pacification foregrounds stability, hegemony, prosperity and power while peacebuilding foregrounds just relationship, mutual care, shared powers, and responsibilities. Future more she claims that elitist vision of peacebuilding gravitates towards pacification including conflict management and violence containment trough special economic packages aiming to steam popular unrest and exceptional special legislation aiming to solve low and order issues in extraordinary situations.

Since academic and expert communities become critical towards understanding of structural or immediate factors that fuels conflicts and violence and started to challenge opinion about successfulness of the strategies for conflict resolution it was reasonable to expect innovative and more thoughtful alternatives and conceptualizations. Such alternatives on the small scale are presented trough critical approach that strategies of conflict resolution delivered as third party intervention are less successful in containing violence, that intervention could in addition fuel violence or to reduce local capacity for peacebuilding or prevent local ownership. Paris argues that..."without exception, peacebuilding missions in the post-Cold War period have attempted to 'transplant' the values and institutions of the liberal democratic core into the domestic affairs of peripheral host states" (Richmond 2013: 271-287). His argumentation regarding peacebuilding practice after the Cold war is that international agencies become more open proponents of liberal political and economic principles in pacification of conflicting societies trough practice of "transmission mechanisms" that could be divided in four categories: instrumental role in shaping peace agreement; impact on implementation of settlement solutions, guidance and assistance; conditionality for financial arrangements and support; and practicing quasi-governmental functions by serving on behalf of local authority (Paris, 2002:645). In other words, peacebuilding as a conflict resolution strategy aims to generate liberal market democracy model that will fit domestic governance. By doing this peacebuilding should not be considered as a pure controller of violence but as a distinctive form of globalization process (according to Paris) or as an instrument for reconstruction and domestic governance.

The literature suggests that there is increased attention to the evaluation of post-conflict arrangements and its un/success (Lotta at all 2006) $)^{1}$. Peace governance is recognized as a dynamic but challenging process often based on institutional and policy arrangements aimed to at least settle conflict dynamics or in other cases even to provide more sustainable peace.

On the other side there are arguments that liberal peacebuilding and statebuilding, including localized practices of peacemaking offers a form of peace that could be legitimate across local and international scale (Richmond, 2013:272287). From this perspective local attempts to create peaceful institutions are of great significance, as it was recognized as bottom up approach for peace formation. Although the importance of local peace potentials are recognized as crucial for successful peacebuilding and maintenance of peace it is difficult to recognize if and in which case legitimate peace formation has been established. Richmond offers conceptualization that peace formation represents autonomous, but often

\footnotetext{
1 Harbom, Lotta, Stina Högbladh and Peter Wallensteen. 2006. "Armed Conflict and Peace Agreements." Journal of Peace Research 43(5).
} 
well-informed, peace oriented, and legitimate discourse...positioned vis-à-vis the conflict, state coming into being and international standards.

Based on the criticism of conflict resolution strategies that are predominantly instrumental in practicing peacebuilding or statebuilding and liberal market democracy norms transfer, the conclusion should be that hybrid forms of peace were neglected or marginalized.

One of the obstacles that could prevent such formation is decision that conflict settlement and peace processes should rely on political elite as stakeholders and key actors in institution building after the conflict. The other obstacle is that non-state or civil society actors are considered important in the process of social peacebuilding and reconciliation but restricted from substantial influence in the process of negotiations or peace settlement. As a consequence partial or substantial resistance forms towards liberal peacebuilding solutions were recognized. The aforementioned are not the sole factors for such kind of resistance but only most obvious ones.

In this way a new possible shortfall of conflict resolution is acknowledged i.e lack of shared vision about causes of conflict and prescription of one side solution for settlement. Some analysts that critically approached peacebuilding practice and achievements now are advocating for the necessity to replace strategies and models that are proven as ineffective. There are suggestions for implementations of the model designed form the ground up in each case in locally resonant ways respecting autonomous agency, capacity, custom, identity, religion, and alternative models of politics, society, and economics and their relations with, resistance to, exposure to, and acceptance of the liberal peace paradigm (Richmond, 2013).

This could be understood as an attempt for more "societal" than political approach to conflict resolution but still not sufficiently clear if such solution will be supported with immediate coercive or non-coercive instruments. Interveners are predisposed to promote political arrangements that correspond to their own governance 'schemas', or taken for-granted assumptions about the nature of political authority. (Paris, $2015139-176$ ). ${ }^{1}$ Peacebuilding and conflict transformation are considered as "governance initiatives" that will facilitate transfer of social and cultural norms into conflict affected society. Sriram looks at power-sharing as peacebuilding along four dimensions: security, territory, politics and economics. Sriram agrees with Paris's criticism of the liberal peacebuilding paradigm and considers the inclusive peacebuilding initiatives she examines in line with Paris's 'institutionalization before liberalization' solution. However, Sriram finds that rushing to institutionalize also brings risks of destabilization and spoiler problems. ${ }^{2}$

In addition, it is important to keep in mind that "countries may be formally democratic but have poor governance according to this definition". ${ }^{3}$

\footnotetext{
${ }^{1}$ Roland Paris, States of mind: The role of governance schemas in foreign imposed regime change, International Relations 2015 , Vol. 29(2) 139-176

2 The concept of hybrid peace governance highlights the mix of norms, institutions, and actors that may emerge in postwar societies. The concept draws attention to overlapping and intertwined power claims and logics of order that arise as international peacebuilding endeavors encounter local institutions and actors. However, a contextualization of the concept, to which this article contributes, reveals a hybridity that is no clear-cut mix of international liberal and local illiberal. While any postwar situation would show examples of hybrid peace governance, the concept helps us focus attention on how hybrid peace governance develops and what its specific dynamics are a victor's peace —enabled more illiberal governance, manifested in a strengthening of the president's power and a closing of political space for opposing voices. A victor's peace is derived from military victory, which implies that a basic power asymmetry is built into the notion of peace.26 in today's globalized world, the lines between who is domestic or local and who is international are blurred. See: Havard Hegre and Havard Mokleiv Nygard, Governance and Conflict Relapse, Journal of Conflict Resolution 59(6); 984-1016

3 The conception of governance captures the entire "chain" or context of implementation that translates the aggregation of preferences into final implementations of policies. Such a wide definition of governance implies that it is a multifaceted concept, and various sources identify different dimensions of it. In this article, we look into seven aspects:
}

(1) bureaucratic quality, (2) the rule of law, (3) corruption, (4) economic policies, (5) military involvement in politics, (6) political exclusion and repression, and (7) formal political institutions. Indicators of quality of governance along these dimensions are drawn from several different data sets. Our conception of good governance involves two distinct aspects: First, those governments intend to implement policies in the public interest and that they succeed in implementing them effectively. We outline six broad categories of "informal institutions" that affect the quality of governance, and contrast them with "formal" institutions of governance. With "formal institutions," we mean de jure institutions that ensure that the executive branch of government is elected by a majority or plurality of the population and that guarantee that the executive is constrained by an elected legislature. The academic consensus of the formal institution-conflict relationship based 


\section{Balkan's multicultural societies}

Given the fact that Balkan countries (former Yugoslav republics) are post-communist and post-conflict societies now on track of democratization and stabilization it is important to emphasize that ethnic and religious diversity and inequality are still among most sensitive issues. From the beginning of 1991 after country proclaimed independence the multi-ethnic and multi-religious characteristics of Macedonian society are considered sensible and possible underlying factors for instability or conflict escalation (H.P Liotta and Cindy R. Jebb 2004:73).

Thus the perception that multi-ethnicity is characteristic of culturally reach region or society has been marginalized and the perception that multi-ethnicity is a source of intolerance, exclusion, discrimination and violence become prevalent (Olivera Simić, Zala Volčič, Catherine R. Philpot. 2012). As Ackermann (2000) and Sokalski (2003) emphasized, until 2001 Macedonian society went trough unique experience in preventive diplomacy and conflict prevention applied by UN and OSCE with the main goal to avert horizontal conflict spillover effects from the region and to prevent vertical escalation of underlying factors within the society. Many authors captured inter-ethnicity as a source of tensions including Leatherman who described Macedonian society as "tinderbox of underlying tensions" (Leatherman, J. ed. 1999 149-180). She referred to different underlying factors but emphasized that relations between Macedonians and Albanians are characterized by sociopolitical, cultural and religious differences reinforced by the territorial homogeneity of the Albanians.

The question of the role of high education in Macedonian multiethnic society has emerged from the broader context of interethnic relations and specifically as an issue of the access to high education of non-majority ethnic groups. It become the most salient aspect of interethnic tensions as access to high education have become politicized and political parties representatives claimed it is a matter of high priority that requires all necessary means to be achieved. The issue of access to high education in short period of time was politicized and even securitized (Stephen May, Tariq Modood, Judith Squires Ethnicity 2004:157). As a consequence the OSCE High Commissioner on National Minorities was involved in approaching education issues on different levels since 1993 (CoE, 2008:31). The core problem could be explained from differing ethnic perspectives i.e ethnic Albanians in the country demanded more favorable conditions and access to high education while Macedonians perceived such claims as repetition of once experienced separatist Serbian-Kosovo scenario. Leatherman quoted data from Macedonian Information and Liaison Service (MILS, 1993:17) about graduate students for Universities is Skopje and Bitola in 1990-1991 as 1.5 percent was Albanians and 87.9 Macedonian (Leatherman, J. 1999: 152). The situation in 2010/11 and 2012/3 according to State statistical office shows that situation is different form 1990-1991 and it is improved. ${ }^{1}$ The numbers presented by State statistical office shows that the access of ethnic communities to high education is improved but the question is whether and how high education contributes for interethnic dialogue and communication.

\section{Peace Agreements and Education}

One of the recent articles published in the Journal of Peace Research introduces Peace Accords Matrix Implementation Dataset, which presents time-series data on the implementation of 51 provisions in 34 comprehensive peace agreements (1989-2012). This article goes over previous available data about implementation of peace agreements as it conclude that there are data about provisions included in peace agreements but not sufficient data about their implementation. Implementation data covers three types of power sharing provisions found in peace accords i.e. military, political and territorial. Joshi at all completed list of aforementioned three with additional 48 negotiated provisions and place it into time series that provides annual implementation data. According to data presented in the article there are 26 most commonly

on global comparisons is that democracy in itself does not reduce the risk of civil war onset-if we take countries' income into account, democracies are no less likely to have internal conflicts than nondemocracies (Muller and Weede 1990; Hegre et al. 2001; Fearonand Laitin 2003; Collier and Hoeffler 2004).

1 Total number of first time enrolled students is 17694 of which 13210 (74.65 percentage) are Macedonians, 2422 (13.68 percentage) are Albanians, 336 Turks, 101 Roma, 116 Vlachs, 225 Serbs, 108 Bosniaks and 115 others. From the total number of students in $2011 / 12$ is 57536 (30 813 female) some 45748 (25 263 female); 79.51 percentage are Macedonians, 7804 (3593) 13.56 percentage \% Albanians, 1 053, 1.83 percentage are Turks, 216 are Romas, 340 are Vlachs, 618 are Serbs, 271 Bosniaks, 288 are others (1 198 unknown). According to data published by SSO there are 55810 enrolled students in high education in 2012/3 (43 828 Macedonians; 8649 Albanians; 1160 Turks; 219 Roma; 423 Vlachs; 750 Serbs; 351 Bosniaks; and 331 oters) Enrolled students in the academic year, 2012/2013 State statistical office of the Republic of Macedonia, pp. Statistical review 2.4.14.14 (796) 2014; http://www.stat.gov.mk/Publikacii/2.4.14.14.pdf 
negotiated provisions (ceasefire as a most frequently included provision, in 29 out of 30 , education in 15 of 30 ) but authors argues inclusion doesn't guaranties provision implementation. Data presented shows that media reforms, decentralization/federalization, human rights, judiciary reform and education reforms (changes to the structure, content, quality, accessibility and/or availability of education) are included in more than 15 out of 31 peace records but this provisions are listed on the bottom of the scale of the implementation. ${ }^{1}$

Another article (Dupuy, 2009) examines specifically the ways in which education has been addressed and incorporated in peace agreements between 1989 and 2005. It argues that not only is education negatively affected by armed conflict, but it can also play a contributory role in the outbreak of conflict. The article thus seeks to develop understanding of the relationships among education, conflict, and peace. In total, 57 out of 103 peace agreements ( 55 percent) signed between 1989 and 2005 mentioned education in some form. Education is largely viewed within peace agreements in four ways: as a security issue, a protection issue, an economic issue and a socio-political issue. Education is viewed as a necessary component of economic development and reconstruction and as a means to achieve self-reliance and alleviate poverty

Mandates for education system reform are also mandates for social and political reform since they require a restructuring of social and political hierarchies.

Education is viewed as a security and protection issue since reforms address the integration of ex-combatants and returned refugees and internally displaced persons into the education system

Educational provision is almost universally viewed as a public service that the state is responsible for delivering.

When education is not included in peace agreements it is often because education is viewed as a developmental rather than a humanitarian issue.

Addressing education in peace agreements can have a number of beneficial impacts. For example, it can:

Increase the likelihood that education will remain a focus post-conflict and that the role education may have played in the outbreak of conflict will be addressed;

Demonstrate a commitment by the state to peacebuilding and transforming the roots of conflict

Help to diffuse dissent

Significantly contribute to building long-term, positive and sustainable peace; it can potentially transform the roots of conflict

Provide an incentive to the laying down of arms, particularly where educational exclusion is a motivation to fight

Be an important step towards building peace through renegotiation of the social contract. ${ }^{2}$

It concludes by providing suggestions for further research to help improve understanding of the added value of including education in peace agreements.

Full and partial peace agreements 1989 2005, intrastate, interstate and internationalized intrastate conflicts (Harbom 2006 ...

43 full peace agreements signed between 1989 and 2005, $3786 \%$ are publicly available. Of 37 publicly available, 11 or 30 $\%$ make no mention of education at all while $2670 \%$ do mention education in some way. In total 57 out of 103 peace agreements (55\%) mentioned education in some form. This agreements stipulate four types of activity to occur in the education sector: respecting and implementing the right to education, resuming education services, responding to conflict created issues within education sector and actively reforming the education system as a way to address the issues at the heart of incompatibility. The state is responsible for the implementation.

Education is viewed within the agreements as a security issue (as integral part of reintegration of ex combatants, formal, non formal or professional education and training, SSR and retraining and reeducation of police and military), a protection

\footnotetext{
1 "Annualized implementation data on comprehensive intrastate peace accords, 1989-2012." Madhav Joshi, Jason Michael Quinn, and Patrick M. Regan. Journal of Peace Research (2015): 551-562

2 Dupuy, K., 2009. 'Education in Peace Agreements, 1989-2005', Conflict Resolution Quarterly, vol. 26, no. 2, pp. 149-166 
issue (protecting from recruitment, mines), an economic issue (poverty reduction trough formal and vocational, and sociopolitical issue (distribution of educational opportunities and resources; access, selection function within the education sector (exams), training and distribution of teachers, educational governance, content of the curricula and language of instruction. Educational exclusion high socio-economical development low

Educational governance includes effective management within the system, participatory management of schools, decentralization of power, authority, control and decision making to state and local level. Content of the curriculum including common values (cooperation, solidarity, respect, responsibility, diversity)

In general three factors contributes for the exclusion of education into peace agreements: education is viewed as developmental rather humanitarian issue; parties are more concerned about direct violence cessation an gain of political power; type of conflict and the perception if and whether education is part of the conflict issues. Context of the country and the specifics of the conflict, how education is linked to the causes, outbreak and dynamic of the conflict, what role can education play in resolving the conflict.

Education should be part of peace agreements and peacebuilding because of three reasons; agenda for post conflict period, program priorities and funding of government, donors and humanitarian organizations. Education will receive attention of institutions involved in peacebuilding process.

\section{What kind of Peace education in the Balkans}

Betty Reardon (Reardon, 1988) in her book titled Comprehensive Peace starting from Johan Galtung classical definition about positive and negative peace (Galtung, 1968) described two peace education approaches as for negative peace (arms race, war and violent conflict) and for positive peace (Boulding "stable peace").

Envisioning peace is a challenge to peace movements and education, Programs focused on the way how conflict is handled trough conflict management and conflict resolution, again negative peace approach. Combination of peace and conflict studies, The other aspect is conflict studies, dealing with conflicts on different level introduced negotiation and dispute resolution skills that are important for all social relations and interactions.

Four categories like political-ideological conflict (as a major causes of conflict), arms race, lack of understanding or misperception of other, inadequate or lack of use of alternative conflict resolution procedures. This is not sufficient to provide a base for comprehensive peace education ...Peace education eliciting awareness and understanding of the problem of war, consciousness -raising; planning, develop values and commitment to action. The cycle of care, concern and commitment is the core of the peace learning process. Education is the social enterprise conducted for the realization of social velues. Positive peace education should include environmental, development and human rights education. ${ }^{1}$

In line with its commitments, Republic of Macedonia needs to transform into a society in which education and training, culture and science represent a key factor for the well-being of its citizens and strengthening its economy. Hence, reforms in education need to ensure greater compatibility between national and EU and global standards, advancement of democracy and civil society, and development of a contemporary integrated market economy. The primary goal of education policy, enshrined in the National Programme for Development of Education 2005-2015 (Ministry of Education, 2005), is to provide opportunities to all and to all age groups for acquiring a suitable educational level, and to ensure that all possess competences commensurate to the demands of society and the labour market.

\footnotetext{
1 Indirect Model of Peace Education is suitable when conditions do not favor direct reference to the ethos of conflict that maintains the intractable conflict. Usually this is the case when conflict continues, violent acts are occur- ring, and a majority of society supports continuation of the conflict and holds a sociopsychological repertoire of ethos of conflict. Direct Model of Peace Education can be launched when the societal and political conditions are ripe and the educational system is ready, both administratively and pedagogically, for this major endeavor. Direct peace education directly refers to themes of conflict and tries to change societal beliefs, attitudes, values, and behaviors related to culture of conflict. An example of direct peace education is the Education for Peace project carried out in Bosnia and Herzegovina in the past decade, which attempted to transform the lives of the students, teachers, and the whole community by directly confronting participants with the issues that were at the heart of the conflict (Clarke-Habibi, 2005). Peace Education in Conflict and Post•conflict Societies: Comparative Perspectivesedited by Claire McGlynn, Michalinos Zembylas, Zvi Bekerman, and Tony Gallagher. New York: Palgrave Macmillan, 2009
} 
In order to achieve this goal, education must be accessible to all, regardless of age, sex, religious and sexual orientation, ethnic affiliation, medical condition and social and financial status. In addition, education and training must fulfill all efficiency and effectiveness requirements in order to be in a position to provide all with sufficient general and vocational education.

The tertiary sector has since 2003 been in a continuous process of change, to the greatest extent caused by the endeavors of the state to implement the Bologna Declaration. After long period of adjustments the new Law on High education was adopted in 2008 reflecting three-cycle based high education system. The period of transition has been filled with a number of initiatives for changing the legislation in education, for decentralising education, for adopting developmental curricula, for strengthening the administrative and professional capacities of the state institutions, for establishing professional bodies, agencies and centres, for changing the structure and organisational set-up of the education system and educational institutions, etc. ${ }^{1}$ All this is a result of the efforts of the state to find optimal solutions that would enable the creation of a functional education system. ${ }^{2}$ It would be justified to call this period a period of substantial education reform.

\section{The role of high education in intercultural communication and dialogue}

Experience so far indicates that the idea of intercultural education draws its strength from the Education for All Declaration, based on the right to education and the right to diversity. Within the framework of these efforts, we can differentiate among: multicultural and multilingual education (in the practice it most frequently takes the shape of bi-cultural and bi-lingual education); education of the culturally different; civic education, education for cultural understanding, international education, education for peace and coexistence, etc.

The Republic of Macedonia is populated by a large number of ethnic groups. According to the latest census of 2002, the population consists of: $64.2 \%$ Macedonians; $25.2 \%$ Albanians; $3.9 \%$ Turks; $1.9 \%$ Serbs; $2.7 \%$ Romanies; $0.8 \%$ Boshnaks, Etc. It is evident that in the Republic of Macedonia, just like in the other Balkan countries, a number of cultures coexist, that have among themselves developed appropriate relations. The rights and obligations of the citizens are regulated with the Constitution and the laws. The Constitution respects the rights of the ethnic communities in the Republic of Macedonia, including the right to education. The right to education is guaranteed through Article 7 (lines 2 and 4), Article 8 (lines 2 and 11) and Article 48. The Constitution guarantees a multitude of rights related to education and to the use of language in municipalities populated by a substantial number (over 20 percentage) of the members of ethnic communities. Articles 44 and 48 are of special significance; they relate to the right of the ethnic communities to self-expression and maintenance of the culture and the cultural identity. Thus, conditions and institutional opportunities are constantly created for education, getting to know each other, building and expressing one's own cultural identity, as a basis for interaction with one's own cultural group and with the other cultural groups in the country.

If intercultural education is enshrined in the right to education in the respective mother tongue of the culturally diverse students, then we can conclude that the Republic of Macedonia, as reflected in the situation of its educational system, respects and implements the idea of intercultural education. Still there is general awareness and criticism that there is no common understanding about the concept of intercultural education and its priorities and goals. There is also general concern that pre-school, primary, secondary and even tertiary education produces more ethnic distance than communication and dialogue.

According to the Ministry of Education and Science of the Republic of Macedonia, multi-ethnicity is reflected in the education system in different ways, with the aim of providing children and youth with education in the mother tongue. That evidently contributed to the significant progress in the implementation of the language rights of the communities in the last decade.

\footnotetext{
1 In addition to the state universities (the "Ss. Cyril and Methodius" University in Skopje, the "St. Kliment Ohridski" University in Bitola, the State University in Tetovo, founded in 2004. the "Goce Delcev" University in Shtip, founded in 2007, and the University of Information Sciences and Technologies "St. Apostle Pavle" in Ohrid, founded in 2009), a significant number of private higher education institutions were opened in the country: the FON University (2002),, the European University - Republic of Macedonia, the American College University and are private higher education institutions with representative numbers of students. A new type of public-private non-profitable higher education institution has been introduced. Currently there is only one university of this type, the South-East European University established in Tetovo in 2001 with financial contributions from numerous international donors and foreign higher education institutions; http://eacea.ec.europa.eu/tempus/participating_countries/reviews/fyromacedonia_review_of_higher_education.pdf
} 
However, the concrete interpretation of the rights of the communities on the part of the country's political factors did not bring about greater integration. On the contrary, the ethnic divide, especially among the smaller children increased, and the knowledge of the other groups became anecdotal. Although on a macro political level interethnic relations are constantly improving as a result of the institutional approach linked to the implementation of the Ohrid Framework Agreement, the insufficient integration on a personal level may be a long-term threat to the very cohesion of society. A more integrated approach in education will not only help avoid bad experiences, but will also contribute to a deeper understanding of the elements building the country's multi-ethnic society and what is needed to make it more stable and coherent.

The ethnic and cultural intolerance among the youth, generated in the area of education could be explained as a consequence of several factors:

- Establishing of parallel education systems, which added the issue of physical distance to the issue of cultural distance;

- Factographical presentation of traditional elements of other cultures in the textbooks and in the teaching process; stress is placed only on cognitive acquisition, with absence of the processes of understanding, valuing and respect. Analyses of textbooks for primary and secondary education reveal that the prevailing contents and ways of their delivering in curricular and extra-curricular activities do not enable a satisfactory degree of mutual knowledge of traditional customs and values, way of life, gender relations, family relations, religion, everyday life, etc (Beska at all. 2009)

- Absence of school and out-of-school activities which presuppose participation of young people from different cultures. In this area, there is almost no state intervention with the purpose of elimination of this anomaly. The main carriers of this type of cultural together-bringing predominantly come from the NGO community. In the recent past, numerous projects have been implemented, which have the objective of promoting cultural communication among members of different ethnic groups in the Republic of Macedonia.

- Poor teacher competencies for teaching intercultural education. A large portion of teachers display teaching competencies focused only on realising a teaching programme of an encyclopaedic character. Unfortunately, teaching competencies for an integrated approach in the delivery of a teaching programme focused on realisation of a given educational output and which would presuppose a more liberal and creative teaching approach, are a rarity. This condition is to a large extend preconditioned by the rigidity of the normative acts and standards currently regulating education, and the character of the curricula and programmes that rarely contain objectives aimed at acquiring, promoting and developing intercultural values.

-Strong influence of the non-formal and the in-formal educational influence (family, local community, church / mosque, media, political parties);

-Absence of clearly defined and nationally and locally accepted goals of education. Purposeless conducting of the educational process most frequently results in improvising and experimenting, in negative reflection on the end result of the process / action. All the more, as education is an area which is oversensitive to such incorrectness, and the negative effects, only visible in the future, remain forever incorrigible. Thus, the use of education in the function of strengthening ethnocentric forces brings about extremely negative implications for the future.

-The political structures (as duty-bearers for the development of the country) do not confirm in their practice the declared goals that are inherent to the pedagogical regulations and in the education as a whole.

It is reasonable to expect that elimination of the last reason is crucial for conditions for true enlivening of the idea of intercultural education and a basic precondition for overcoming of all enumerated weaknesses in the education sphere.

\section{The role of the Universities}

The internal transformation processes and the planetary globalization processes have made a strong impact on the redesigning of the overall structure of society, giving rise to the need for national and international cooperation and compatibility of systems, and thus also to the innovation of the role and structure of higher education, as a significant factor in achieving that compatibility. The need for a strategic approach to the transformation of higher education is a consequence not only of the changes on a national level, but also of the external, i.e. global and general influence factors shaping higher education in other countries. On 19th September 2003, the Republic of Macedonia became a full member of the European family of countries committed to following and implementing the Bologna Process recommendations and common pledge for creation of a single European Area of Higher Education. When the state assumed obligations from the Bologna Process, 
higher education became faced with new challenges for its further transformation. In addition to efforts for improving the quality and efficiency of the studies, higher education is also confronted with the obligations for its own structural, organizational and curricular designing, which would make it transparent, competitive, compatible and recognizable on the European market of high education (HE) services. The initiatives for creation of a common European Area of Higher Education forced the higher education institutions to re-examine themselves, and gave them additional impetus for investing efforts on their way towards active membership in the family of European universities and obtaining the status of respectable providers of educational services on the broad European academic market.

It was obvious that higher education faced the need for: structural adaptation of the tertiary education system to the Bologna Process; harmonization of legislation with the principles and recommendations of the Bologna Process; harmonization of requirements and standards of higher education; creation of an efficient system of scholarships that would facilitate enhanced education and mobility of students and teachers; promotion of European cooperation in quality assurance through development of comparable criteria and methodology; strengthening the system for external evaluation of the quality in higher education; defining of and strict adherence to the standards for founding and accreditation of private higher education facilities; development of an efficient system for financing higher education and allocation of funds; improvement of strategic and managerial capacities; development of scientific and technological strategies; transparent financing of science research; establishment of a data base of national innovations systems in higher education.

To this end, the government of the Republic of Macedonia adopted a Programme for the Development of Higher Education for the period 2006-2010. It was important to ensure that the overall transformation of higher education would be completed in the given period, in order to ensure a dynamics compatible to the changes in the European countries and its active involvement in the European Area of Higher Education.

2003 saw the adoption of the Law on Amendments and Supplements to the Law on Higher Education, obligating universities to introduce the ECTS and design their study programmes and subject curricula according to the principles of the Bologna Process. However, the conditions under which the changes were made were characterised by pronounced slowness and lack of coordination. The Law on Higher Education and the internal documents adopted by the universities and higher education institutions did not provide for clear instructions for reforming higher education. Thus, the majority of faculties individually approached the transformation of the study and subject curricula. The attempt to implement those Bologna Process principles pertaining to changes in the structure of higher education institutions, primarily the duration of undergraduate and postgraduate studies, initiated huge debates and reactions in the university community.

Higher education institutions made interventions in their structure in line with the provisions of the Law. It turned out that the three-year undergraduate studies model was difficult to accept. The majority of faculties stuck to the previous duration of the studies of 4 and in some cases 5 years, and only a small part introduced study programmes of 3 -year duration. The present lack of coordination in the transformation of study programmes brought about cases when a single profile, can be acquired at different faculties through study programmes with different duration namely both in three or in four years.

In 2008 a new Law on higher education was adopted. This law made the effort to approximate higher education to the Bologna recommendations. Its goal was to create preconditions for the transformation of the decentralised into integrated universities. The part governing teaching contains provisions regulating transformation of the studies and the study programmes according to the ECTS. It also regulated the management (introduction of a university board, modification of the role of the university management and strengthening the competence of the Senate and especially of the Chancellor). Significant changes were introduced in the procedures for election and re-election of teaching staff. Unfortunately, this law lacked the courage to introduce changes also in the area of financing and in changing the status of the Accreditation Board and the Agency for Evaluation towards their professionalisation and distancing from the possible influences of the state authorities and institutions. All in all, the law strengthened the influence of the state in higher education. This influence has continued to grow in the following period, through frequent amendments to the law and introduction of provisions highlighting the control and penal role of the state. This trend reached its pinnacle with the adoption of the new Law on State Servants transforming the status of the staff of higher education institutions into state servants.

In the same period, the Law on Amendments and Supplements to the Law on Higher Education was adopted. The amendments eliminated the title of associates at the university and introduced clinical teaching in higher education. In an environment of shortage of teaching and assisting personnel, the universities faced an additional challenge - loosing 
associates. This measure sparked a reaction by the universities and mobilisation of the staff with associate status towards completing their master's and doctoral studies.

One of the more significant reforms in higher education was the introduction of Albanian as a language of instruction in higher education. At the beginning of 1997, the Ministry of Education adopted a Bill on Languages of Instruction at the Pedagogical Faculty St. Clement of Ohrid - Skopje. This Bill sparked a wave of discontent among some of the academic and political stakeholders. The Bill introduced the possibility for students from the Albanian minority to receive instruction in their mother tongue. This initiative received its full implementation through the Law on Higher Education from 2000. Significant features of this Law are the introduction of minority languages in higher education, of the possibility for establishment of private higher education institutions and of the establishment of professional bodies for accreditation and evaluation. This Law enabled the establishment of the South East European University (SEEU) in Tetovo.

Today, five state universities operate in the Republic of Macedonia with 57 faculties, as well as six private universities with 42 faculties and over 50 study programmes dispersed outside of the university centres. In addition to the older universities (the Ss. Cyril and Methodius University in Skopje and the St. Clement of Ohrid University in Bitola), starting in 2001 the number of state funded universities increased for three new ones. In 2000, the OSCE High Commissioner for National Minorities initiated the creation of a foundation of international donors which would help the establishment of a new university in the Republic of Macedonia. Following the adoption of the Law on Higher Education by the Parliament of the Republic of Macedonia, this allows for the founding of universities without state funding and with Albanian as main language of instruction, the detailed planning commenced towards the end of 2000. The construction started in March 2001 and six months later the South East European University (SEEU) opened its doors to 900 students. By October 2002, the number of students had gone up to 2250, with 3700 students attending the SEEU in October 2003. 2004 saw the opening of the State University in Tetovo, with the Goce Delchev University founded in Shtip in 2007 and the St. Paul the Apostle University for Information Technologies established in Ohrid in 2009.

As regards the strengthening of the state capacities in the area of higher education, we need to mention that in 2000 the Higher Education Accreditation Board and the Agency for Evaluation of Higher Education in the Republic of Macedonia were set up. These two bodies were supposed to "bring order" into higher education, i.e. to instigate external mechanisms for assessment of the degree of fulfillment of the necessary preconditions and quality for founding and operation of higher education institutions, and for ongoing evaluation of the quality of higher education in the country. Since its establishment, until 2010, the Evaluation Agency failed to fulfill its role as stipulated in the provisions, while the work of the Accreditation Board has frequently received criticism. Until today, it did not manage to establish itself as an independent body and is to a large degree dependent on the Ministry of Education and Science. In 2010, these two bodies were merged, operating as an Accreditation and Evaluation Board, under strong influence of the state.

\section{Initiatives for improvement of intercultural education}

In the period since gaining independence, many changes and amendments to the legislation and a number of strategic documents, developmental programmes and measures have been adopted, all of which had as their aim not only the improvement of the situation in education, but also the strengthening of the intercultural dialogue in the Republic of Macedonia. At the beginning of 1997 the Draft Law on the Languages of Instruction at the St. Clement of Ohrid Pedagogical Faculty in Skopje was adopted. The Law envisaged the possibility for the students of Albanian nationality to attend instruction in their own mother tongue. Despite the reactions of the general public, the Parliament of the Republic of Macedonia adopted at the first continuation of its 58th session, held on 30th January 1997 the Draft Law on the Languages of Instruction at the St. Clement of Ohrid Pedagogical Faculty in Skopje.

In 2000, the OSCE High Commissioner for National Minorities initiated the creation of a foundation of international donors to help the establishment of a new university in the Republic of Macedonia. Thus, 2000 saw the adoption of a new Law on Higher Education This law introduced several new solutions in higher education, namely the introduction of the languages of the minority groups in higher education, the possibility for founding of universities without state funding and with the Albanian language as the main language of instruction, the creation of preconditions for founding of private higher education institutions and the establishment of professional bodies for accreditation and evaluation. Thus, as a direct result of this law, the South-East European University was founded in Tetovo, starting officially its operation in 2001. The Ministry of Education and Science of the Republic of Macedonia concluded in 2010 that despite the significant progress of the education system in the past decade in the area of mother tongue education, developments are taking a course that needs 
attention and correction, in order to avoid a greater ethnic divide, brought about by insufficient knowledge of the others, by decreasing interaction, all as a consequence of the serious lack of familiarity with the language.

With joint efforts, and as follow-up measures to the recommendations by the OSCE High Commissioner for National Minorities (OSCE HCNM) from January 2008, the Ministry of Education and Science and OSCE developed the strategic document Steps towards Integrated Education in the Education System of the Republic of Macedonia, as an overarching government strategy towards an integrated education system. The goal was to introduce a clear and significant change to the general approach in the education system in accordance with the multiethnic reality in the country, as a step towards achievement of the strategic goals of the country, for which stability and internal cohesion are as crucial as are good interethnic relations. This policy reflects the Constitution and the legislation respectively resulting from the Ohrid Framework Agreement. The measures provided in this document are divided into five thematic groups:

The first thematic group included integration through joint activities of students attending instruction in different languages, provides measures for introduction or strengthening joint curricular and extracurricular activities on different levels: in the schools themselves and between different schools in the same municipality or from the entire country;

The second group of measures focuses on integration through increasing the mutual familiarity with each other's languages among students and adults, increasing the communication between members of the different communities. One subgroup of measures is aimed at training teachers in the methodology of teaching the students' second language, with emphasis on the language of the smaller ethnic communities;

The third group of measures proposes adaptation of the syllabus and curricula and the textbooks, with emphasis on history, geography and language textbooks, as well as improvement of the mechanisms for approval of and control over textbooks. The adaptation of the curricula from primary and secondary education aims at giving schools space to identify the needs of their respective environments, as well as to include the concept of education for tolerance and intercultural communication and understanding in all aspects of teaching. The introduction of the subject History of Religions is also planned, accompanied by measures ensuring that teachers are adequately trained to teach it;

The fourth group of measures is aimed at strengthening the qualification of teachers with competencies for integration. This requires pre-service training in interethnic issues, introduction of regular in-service training for teachers and school directors, and introduction of a system for external evaluation and monitoring of teachers' abilities. It is also proposed that preschool education is involved in the implementation of these measures.

The fifth group of measures included the management of schools in a decentralised context. It proposes measures for strengthening the job security of teachers, for defining conditions for employment of deputy directors, of municipal inspectors and municipal education advisers, followed by defining of education responsibilities of the state institutions visà-vis those of the municipal authorities, thus strengthening the cooperation both at a national as well as on a local level.

Besides aforementioned, additional measures are proposed for further depolitisation of the education system and for enhancement of the involvement of all stakeholders in the management of schools. This document also highlights the need for introduction of a process of regular consultations between all stakeholders, which will function as a participative democratic corrective measure. The review of the document shows that the emphasis is on the primary and secondary education role and its contribution on integrated education in Macedonia. Jet the document do not refer on the role of high education as an actor in integrated education. The role of high education institutions is mainly recognized trough teacher's competences.

\section{Conclusions}

The future of intercultural education in the Republic of Macedonia depends on shared understanding of its mission and its goals if not on common vision about what intercultural education means. As it was the case in the past, the high education in Macedonia is affected and will suffer from the challenges arising from the social, economic, interethnic and political issues.

The specific objectives and tasks of education must be geared towards promotion and development of the individual characteristics of the personality through the processes of getting to know, understand and respect of other cultures, at national and international level, with the purpose of development of the individuality, his/her interests, attitudes and motives. 
This process needs to be raised to a level of self-educational activities, so that the individual is in a position to situate him/herself in the world of a narrow and wider social and working environment.

The role of high education should be directed to foster intercultural dialogue and development trough supporting instruments (policies, strategies) that:

on one hand, provide multiply opportunities for interaction between ethnic communities and,

at the same time, create some "pressure" on the national level (for example, through the sets of standards to HE, economic instruments, incorporating a new value system into the functioning of the society, etc.) that stimulate HE institutions, as well as other stakeholders, to implement the educational reform more actively.

It is very important that the high education institutions, while acknowledging the positive practices within (mixed campuses, availability of courses in several languages, extra-curricular activities, etc.) realise the limitations of these approaches within the concept of Integrated Education and raise the issues of redefining the concept of HE, which is more broad, inclusive, and humanistic, and addresses the needs of the whole society, rather than over-concentrating on accommodating the needs of separate ethnic groups.

The content of education has to be changed as it is critical that curriculum reform promotes the development of skills, values and behaviours that allow students to participate more actively in the society and that are coherent with the notions of democratic and cohesive society;

Teaching practices have to be changed; In order to address the diverse needs of students, also from different ethnic communities, teaching has to become more student-centred; at the moment, the most staff do not feel comfortable with the mixed student campuses and classrooms and also teaching about inter-cultural relations, since it requires rethinking the whole approach to learning, which allows seeing the perspective of " others" from their own point of view, but not through the textbook or lecture;

Achieving the goal of bringing the students from different ethnic communities to study together still creates a problem for the HE institutions; although some courses are attended by Albanian and Macedonian students, it is done through the means of the third language (i.e. English), while other courses are provided only in Macedonian or Albanian;

Defining a new concept of HE (or vision) creates a challenge that has to be addressed on the national level; the lack of clear definition what the quality of education is within the integrated education framework prevents from the development of the appropriate standards and requirements in higher education; moreover, it may jeopardise the process of implementation of the national strategy, since the quality criteria for the HE are not defined;

The University could contribute for the cultural dialogue enforcement; still the University is not capable of removing all omissions happened during primary or secondary education or non-school life. Enhancing of intercultural dialogue is not exclusively University issue but of the broader community and family. It requires holistic approach and measures in order to bring some positive results.

\section{References}

[1] (796) 2014; http://www.stat.gov.mk/Publikacii/2.4.14.14.pdf

[2] Cambrige University Press, 2004

[3] conflict in Central and Eastern Europe, Council of Europe Publishing

[4] Crises. Kumarian Press (149-180)

[5] Daniel Bar-Tal and Yigal Rosen: Review of Educational Research, June 2009; vol. 79, 2: pp. 557-575. first published on February 25, 2009 http://rer.sagepub.com.ezproxy.ub.gu.se/content/79/2/557.full.pdf+html

[6] David Carment, Albrecht Schnabel. (2003). Preventive Diplomacy Conflict Prevention:

[7] Dealing with a Violent Past while Building, Springer, 2012 (17-75)

[8] Education System of the Republic of Macedonia, Skopje

[9] Education. (online) Available: http://www.seeeducoop.net/education_in/pdf/mak-strategija-mk.pdf

[10] from 19.08.2008 State statistical office. http://www.stat.gov.mk/Publikacii/2.4.13.15.pdf 
[11] Georgieva,L.Memeti A. and Musliu, A. (2011). Patterns of conflict resolution in the

[12] H.P Liotta and Cindy R. Jebb, (2004). Mapping Macednia: Idea nad Identity, Praeger

[13] Henryk, J. Sokalski. (2003). An Ounce of Prevention: Macedonia and the UN Experience

[14] http://online.sagepub.com.ezproxy.ub.gu.se/search/results

[15] http://pfe.sagepub.com.ezproxy.ub.gu.se/content/10/5/528.full.pdf+html

[16] http://www.see-educoop.net/education_in/pdf/mak-strategija-mk.pdf

[17] http://www.ucimezaedno.mk/Documents/Strategy_IE_English.pdf

[18] Improving access and opportunity: higher education in transition in Macedonia

[19] in Preventive diplomacy. USIP. Washington DC

[20] Integrated Education in the Education System of the Republic of Macedonia.

[21] Joanne Hughes, Simon Lolliot, Miles Hewstone, Katharina Schmid, and Karen Carlisle

[22] Kevin Kester; The Case of Educational Peacebuilding Inside the United Nations Universities: A Review and Critique; Journal of Transformative Education, 1541344616655888, first published on June 26, 2016http://jtd.sagepub.com.ezproxy.ub.gu.se/content/early/2016/06/24/1541344616655888.full.pdf+html

[23] Law on Primary Education, Official Gazeete of the Republic of MAcedonia No.103/08

[24] Leatherman, J. (1999). Breaking Cycles of Violence: Conflict Prevention in Intrastate

[25] Michalinos Zembylas and Zvi Bekerman; Integrated Education in Conflicted Societies: Is There a Need for New Theoretical Language? European Educational Research Journal, September 2013; vol. 12, 3: pp. 403415.

[26] Mieke T.A. Lopes Cardozo; Sri Lanka: In Peace or in Pieces? A Critical Approach to Peace Education in Sri Lanka; Research in Comparative and International Education, March 2008; vol. 3, 1: pp. 19-35.

[27] Ministry of Education and Science (2010): Steps towards Integrated Education in the

[28] Ministry of Education and Science of the Republic of Macedonia. Steps Towards

[29] Ministry of Education and Science. National Strategy for the development of education in

[30] Narratives and Peace Education Program Journal of Peace Research, March 2006; vol. 43, 2: pp. 167-180.

[31] National Programme for Development of Education 2005-2015, Skopje Ministry of

[32] Olivera Simić, Zala Volčič, Catherine R. Philpot (eds).Peace Psychology in the Balkans:

[33] Path to Peace Or Grand Illusion? USIP. Washington DC. (pp.47-69)

[34] Pavel Zgaga, Manja Klemenčič, Janja Komljenovič, Klemen Miklavič, Igor Repac,

[35] Peace Education in Societies Involved in Intractable Conflicts: Direct and Indirect Models

[36] Policy Futures in Education, October 2012; vol. 10, 5: pp. 552-562. http://pfe.sagepub.com.ezproxy.ub.gu.se/content/10/5/552.full.pdf+html

[37] Publishers

[38] Report of an OECD review, 2004 http://www.oecd.org/edu/imhe/32109399.PDF

[39] Republic of Macedonia, Institute for British-Irish Studies University College Dublin; IBIS Discussion Paper No. 8. (online) available: http://www.ucd.ie/ibis/publications/discussionpapers/patternsofconflictresolutionintherepublicofmacedonia/

[40] Sara Clarke-Habibi;Transforming Worldviews: The Case of Education for Peace in Bosnia and Herzegovina; Journal of Transformative Education, January 2005; vol. 3, 1: pp. 33-56.

[41] Sharing Classes between Separate Schools: A Mechanism for Improving Inter-Group Relations in Northern Ireland? Policy Futures in Education, October 2012; vol. 10, 5: pp. 528-539.

[42] State statistical office of the Republic of Macedonia, pp. Statistical review , 2.4.14.14

[43] Stefan Wolff, Marc Weller eds.(2008). Institutions for the management of ethnopolitical

[44] Stephen May, Tariq Modood, Judith Squires Ethnicity, Nationalism, and Minority Rights,

[45] the Republic of Macedonia 2005-2015. (259-318)

[46] Tomovska. Study on multiculturalism and inter-ethnic relations in Education.UNICEF Office Skopje, 2009

[47] Vedran Jakačić. Higher education in the Western Balkans: Reforms, developments,trends.Faculty of Education. Ljubljana. 2013 http://www.herdata.org/public/hewb.pdf

[48] Violeta Petroska-Beska, Mirjana Najcevska, Nikolina Kenig, Safet Ballazhi, and Ana 
[49] Yifat Biton and Gavriel Salomon; Peace in the Eyes of Israeli and Palestinian Youths: Effects of Collective

[50] Zvi Bekerman Teachers' 'Contact' at the Integrated Bilingual Schools in Israel 